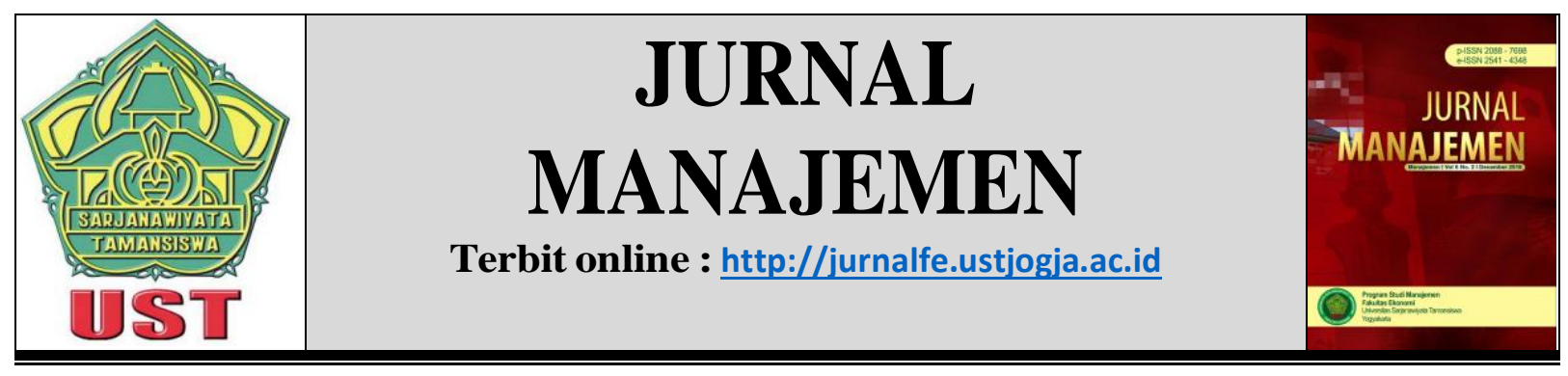

\title{
SIKAP TERHADAP M-BANKING DAN DAMPAKNYA TERHADAP BEHAVIORAL INTENTION TO ADOPT M-BANKING (Studi Pada PT Bank Syariah Mandiri Semarang)
}

\author{
Ken Sudarti ${ }^{1}$ \\ Susi Susanti ${ }^{2}$ \\ ${ }^{1,2}$ Fakultas Ekonomi Universitas Islam Sultan Agung \\ Korespondensi: kensudarti@unissula.ac.id
}

\begin{tabular}{ll}
\hline Informasi Naskah & Abstrak \\
\hline Diterima: & This paper aims to know the effect of Perceived Usefulness, \\
29 Maret & Perceived Ease of Use, Perceived Risk, and the effect of M- \\
Revisi: & Banking toward behavioral intention of PT Bank Syariah Mandiri \\
$16 \mathrm{Mei}$ & Semarang. The samples of this research were used 100 \\
Terbit: & respondents. This paper used convenience sampling by using SPSS \\
20 Mei & as data collection. The result showed that Perceived Usefulness, \\
\hline Kata Kunci: Perceived & Perceived Ease of Use, and perceived Risk have positive effect to \\
Usefulness, Perceived & the M-Banking. Perceived Usefulness, Perceived Ease of Use, \\
Ease of Use, Perceived & Perceived Risk, and M-Banking have positive effect to Behavioral \\
Risk, Sikap terhadap M- & \\
banking dan Behavioral & Intention. \\
Intention &
\end{tabular}

\section{PENDAHULUAN}

Perkembangan teknologi informasi dan komunikasi yang semakin maju di berbagai belahan dunia telah membawa perubahan yang besar terhadap berbagai sektor kehidupan kita. Beberapa sektor yang mengalami perubahan akibat perubahan akibat dari perkembangan teknologi informasi dan komunikasi antara lain perekonomian, sosial, budaya, pertahanan dan keamanan serta pendidikan. Dunia bisnis juga tak luput dari pengaruh teknologi informasi ini, bukti nyata akan adanya pengaruh tersebut adalah adanya $e$-business yang berkembang dengan pesat.

Persaingan yang ketat baik antar bank syariah maupun dengan bank konvensional meningkatkan standar nasabah terhadap kualitas jasa perbankan sehingga pendekatan menggunakan sentiment syariah menjadi tidak lagi efektif. Masyarakat yang sudah terbiasa dengan sistem konvensional dan memiliki image bahwa pelayanan bank konvensional lebih 
baik dari bank syariah menjadi tantangan bagi bank syariah untuk menemukan strategi yang lebih tepat dalam mempertahankan nasabah dan meningkatkan pangsa pasar. Salah satu produk perbankan yang banyak diminati nasabah sebagai strategi yang diberikan perbankan adalah internet banking.

Penggunaan internet banking, memungkinkan bagi nasabah untuk melakukan dial dan menggunakan software internet service provider bank. Tipe banking ini memungkinkan nasabah untuk mengakses rekening bank di lokasi yang tersedia akses internet (Kusuma dan Susilowati, 2007). Hasilnya, para pemakai jasa internet perbankan yang terdaftar dapat melaksanakan transaksi perbankan umum seperti membayar tagihan, pemindahan dana, pembelian pulsa handphone, serta meminta keterangan saldo rekening dan masih banyak jasa perbankan lainnya.

Bank yang sudah menawarkan internet banking di Indonesia yaitu Bank Rakyat Indonesia, (BRI), Bank Danamon, Bank Mandiri, Bank Syariah Mandiri (BSM), Bank Mega, Bank International Indonesia (BII), Bank Central Asia (BCA), BNI, BNI Syariah, Bank CIMB Niaga, Bank Lippo dan beberapa bank lainnya.

Sebagai upaya dalam menjaga eksistensi maka PT Bank Syariah Mandiri Semarang terus berinovasi dalam menerapkan teknologi informasi yang telah menjadi bagian dari gaya hidup masyarakat dan senantiasa meningkatkan kualitas layanan, memperluas jaringan cabang seluruh Indonesia dan meningkatkan jaringan transaksi elektronik salah satunya melalui layanan yang berbasis internet.

Selain persepsi manfaat, kemudahan penggunaan merupakan faktor penting yang diperhatikan nasabah dalam penggunaan jasa layanan perbankan, tidak jarang nasabah juga mempertimbangkan penggunaan layanan mobile banking dikarenakan sistem yang rumit sehingga nasabah masih cenderung lebih memilih menggunakan layanan ATM yang sekedar mengecek saldo, transfer, dan membayar tagihan melalui ATM. Menurut Wibowo (2008).

Faktor kepercayaan juga berpengaruh terhadap sikap positif penggunaan layanan mobile banking. Kepercayaan adalah suatu gagasan dekriptif yang dianut oleh seseorang tentang sesuatu (Kotler, 2006). Seiringnya maraknya kejahatan internet seperti pembobolan akun, faktor kepercayaan menjadi hal yang sangat penting dalam penggunaan mobile banking sebagai transaksi perbankan.

Akan tetapi pada Tahun 2014 terdapat gap pada Bulan Desember yaitu 19,3\%, Tahun 2015 gap tertinggi pada Bulan Januari yaitu 16,9\% dan Tahun 2016, gap tertinggi pada Bulan Agustus yaitu 10\%. Fenomena ini dipicu dengan maraknya tindak kejahatan internet dengan menggunakan fasilitas internet banking di Indonesia, seperti kasus pada BCA pada tahun 2014 sampai dengan 2015 berupa penipuan registrasi melalui website palsu yang mirip dengan alamat situs resminya BCA serta pembobolan rekening nasabah BCA, BNI dan Bank Permata yang diduga dilakukan dari internet banking dengan menggunakan Trojan Zeus yang disusupkan ke dalam browser

\section{KAJIAN PUSTAKA DAN HIPOTESIS Perceived Usefulness}

Menurut Jogiyanto (2007) persepsi manfaat sejauh mana seseorang percaya bahwa menggunakan suatu teknologi akan meningkatkan kinerja pekerjaanya. Menurut Wibowo (2008) mengatakan bahwa persepsi manfaat didefinisikan sebagai suatu ukuran yang mana penggunaan suatu teknologi dipercaya akan mendatangkan manfaat bagi orang yang menggunakanya. Persepsi manfaat didefinisi sebagai sejauh mana seseorang meyakini bahwa penggunaan sistem informasi tertentu akan meningkatkan kinerjanya. 
Dari definisi tersebut diketahui bahwa kegunaan persepsian merupakan suatu kepercayaan tentang proses pengambilan keputusan. Jika seseorang merasa percaya bahwa sistem berguna maka dia akan menggunakannya. Sebaliknya jika seseorang merasa percaya bahwa system informasi kurang berguna maka dia tidak akan menggunakannya. Konsep ini juga menggambarkan manfaat sistem bagi pemakainya yang berkaitan dangan produktivitas, kinerja tugas atau efektivitas, pentingnya bagi tugas, dan kebermanfaatan secara keseluruhan.

\section{Perceived Ease Of Use}

Menurut Katz dan Gurevitch (1974 dalam Fiske, 2007) uses and gratifications ini bertujuan untuk menjawab atau menjelaskan bagaimana pertemuan antara kebutuhan seseorang dengan media, atau lebih khusus lagi informasi yang terdapat dalam media, terutama media masa. Dalam teori ini, khalayak tidak lagi dipandang sebagai orang yang pasif, menerima begitu saja semua informasi yang disajikan oleh media, tetapi mereka berlaku aktif dan selektif, serta kritis terhadap semua informasi yang disajikan oleh media.

Perceived ease of use didefinisikan Chin dan Todd (2011) mengemukakan seberapa besar kemudahan dalam menggunakan komputer untuk dimengerti dan dipahami. Bagaimana cara transaksi atau operasional berbelanja secara online merupakan salah satu faktor kemudahan yang berkaitan. Calon pembeli secara online pertama kali dalam berbelanja merasa faktor keamanan tidak terpenuhi dan tidak tahu cara bertransaksi hal ini dapat mempengaruhi keputusan calon pembeli tersebut. Jika dikaitkan dengan sistem berbelanja online, kemudahan disini dapat diartikan bahwa pembeli merasa tidak mengalami kesulitan pada saat melakukan proses berbelanja online. Pembeli online percaya bahwa situsonline shopping yang mudah pengoperasiannya, mudah dipahami, mudah dipelajari merupakan karakteristik kemudahan.

\section{Perceived Risk}

Perceived Risk atau persepsi risiko didefinisikan oleh Oglethorpe (2014) sebagai persepsi konsumen mengenai ketidakpastian dan konsekuensi - konsekuensi negatif yang mungkin diterima atas pembelian suatu produk atau jasa. Sementara itu, Assael (2014) menyatakan bahwa Perceived of Risk menjadi salah satu komponen penting dalam pemrosesan informasi yang dilakukan oleh konsumen. Konsumen semakin terdorong untuk mencari tambahan informasi ketika dihadapkan pada pembelian produk dengan risiko tinggi.

Ketika persepsi risiko menjadi tinggi, ada motivasi apakah akan menghindari pembelian dan penggunaan atau meminimumkan risiko melalui pencarian dan evaluasi alternatif prapembelian dalam tahap pengambilan keputusan. Kondisi ini menghasilkan pengambilan keputusan yang kompleks. Konsumen mungkin akan mengevaluasi merek secara detail. Informasi mengenai produk sangat dibutuhkan dan konsumen mencoba mengevaluasi berbagai merek. Proses pengambilan keputusan yang demikian menggambarkan adanya keterlibatan konsumen dengan suatu produk. Maka dapat dinyatakan bahwa perceived of risk adalah persepsi atau pemikiran tentang risiko yang akan dialami oleh konsumen. Suatu ketidakpastian dan konsekuensi-konsekuensi negatif yang mungkin diterima atas pembelian suatu produk atau jasa.

\section{Sikap Terhadap M-Banking}

sikap (Attitude) sebagai jumlah dari afeksi (perasaan) yang dirasakan seseorang untuk menerima atau menolak suatu objek atau perilaku dan diukur dengan suatu proseduryang menempatkan individual dalam skala evaluatif dua kutub, misalnya baik atau jelek; setuju atau 
menolak, dan lainnya.

Fishbein dan Azjen (2005), mendenifisikan sikap sebagai penilaian atau evaluation positif atau negatif terhadap suatu obyek. Pengertian ini membatasi sikap hanya pada komponen affective saja. Komponen ini merupakan komponen utama yang terlibat dengan sikap. Pengertian ini sesuai dengan pengertian sikap terhadap merek yaitu kecenderungan untuk mengevaluasi merek baik yang disenangi maupun yang tidak disenangi Azwar (2003). Sikap konsumen dapat menjadi kontrol yang akurat terhadap perilaku pembelian Dharmmesta (1998), dan dapat mempengaruhi pola piker individu dalam pengambilan keputusan.

\section{Behavioral Intention}

Menurut Sihombing (2004), perilaku dapat dibedakan menjadi tindakan, kegiatan, dan hubungan. Tindakan adalah pergerakan fisik dalam waktu yang pendek. Kegiatan didefinisikan sebagai tindakan-tindakan yang berulang kali dalam waktu yang relatif panjang. Perilaku membeli didefinisikan sebagai : segala sesuatu yang dilakukan oleh manusia, Perubahan dalam materi atau non materi yang disebabkan langsung oleh manusia, perilaku juga merupakan hasil dari proses mental.

Perilaku muncul sebagai hasil interaksi antara tanggapan dari individu terhadap stimulus yang datang dari lingkungannya agar bisa beradaptasi dan tetap bertahan yang mendasari timbulnya perilaku adalah dorongan yang ada dalam diri manusia, sedangkan dorongan merupakan usia jadi perilaku muncul karena adanya dorongan untuk bertahan. Notoatmodjo (2003) mengungkapkan ada tiga unsur utama dalam perilaku yaitu: adanya afektif (perasaan atau penilaian pada berbagai hal), kognitif (pengetahuan kepercayaan atau pendapat tentang suatu obyek), psikomotor (niat serta tindakan yang berkaitan dengan suatu obyek).

\section{Hubungan Perceived Usefulness, Perceived Ease Of Use, dan Perceived Risk terhadap Sikap Terhadap M-Banking}

Kegunaan yang dirasakan telah dikonfirmasi yang dapat menjadi penting dalam mempengaruhi niat dan penggunaan. Hasil penelitian Tjayono (2010) menunjukan faktor yang mempengaruhi sikap positif penggunaan internet banking adalah manfaat, variabel manfaat berpengaruh signifikan terhadap sikap positif. Sejalan juga dengan hasil penelitian Safeena (2009), hasil penelitian menunjukan Kemanfaatan yang dipersepsikan berpengaruh positif dan signifikan terhadap penggunaan sistem informasi (internet banking)..

Penelitian ekstensif telah memberikan bukti bahwa kemudahan penggunaan dirasakan memiliki efek signifikan pada niat penggunaan, ini merupakan prediktor penting. Kemudahan penggunaan yang dirasakan dapat menjadi faktor penentu yang penting, bahkan mungkin lebih dari sekedar kegunaan yang dirasakan, keberhasilan sistem informasi ketika masalah yang berorientasi pada proses berada di garis depan pikiran pengguna Venkatesh (1999). Sejumlah penelitian sebelumnya mendukung efek signifikan dari persepsi kemudahan penggunaan padaniat perilaku, baik secara langsung maupun tidak langsung melalui perceived usefulness danattitudemisalnya (Davis et al., 1989; Jackson et al., 1997; Venkatesh, 1999).

Penelitian yang cukup banyak telah meneliti dampak risiko terhadap pengambilan keputusan konsumen tradisional (Lin, 2008). Enam komponen atau jenis risiko yang dirasakan telah diidentifikasi, kinerja keuangan, kinerja, sosial, fisik, keamanan dan waktu (Jacoby dan Kaplan, 1972; Roselius, 1971). Namun, dimensi risiko yang dirasakan dapat bervariasi sesuai kelas produk Novi (2003).

Oleh karna itu dalam penelitian ini di ajukan hipotesis sebagai berikut: 


\section{H1 : perceived usefulness berpengaruh positif terhadap Sikap terhadap M-banking H2 : perceived ease of use berpengaruh positif terhadap Sikap terhadap M-banking H3 : Perceived risk berpengaruh positif terhadap Sikap terhadap M-banking.}

\section{Hubungan Perceived Usefulness, Perceived Ease Of Use, Perceived Risk, dan Sikap Terhadap M-Banking terhadap Behavioral Intention}

Kegunaan yang dirasakan (PU) didefinisikan sebagai "probabilitas subjektif pengguna prospektif itu dengan menggunakan sistem tertentu akan meningkatkan kinerjanya. Berdasarkan Schultz dan Slevin (1975), yang melakukan penelitian eksploratif menyimpulkan bahwa perceived usefulness memberikan prediksi yang dapat diandalkan untuk prediksi model penggunaan keputusan yang diprediksi sendiri. Model ini diperpanjang oleh Robey (1979), dan menegaskan bahwa ada korelasi tinggi adaantara kegunaan yang dirasakan dan penggunaan sistem. Penelitian sebelumnya menunjukkan bahwa adahubungan positif antara kegunaan yang dirasakan dan niat untuk menggunakan (Karahanna, Straub, \& Chervany, 1999; Guriting dan Ndubisi, 2006).

Menurut Karahanna dkk. (1999), disimpulkan bahwa perceived ease of use memiliki efek positif yang signifikan pada niat untuk mengadopsi perangkat lunak di kalangan pengadopsi potensial. Begitu pula nasabah bankcenderung mengadopsi perbankan online bila mudah menggunakan teknologi tersebut Guriting \& Ndubisi (2006). Demikian juga, berdasarkan Lau (2002), disimpulkan bahwa perceived ease of use secara signifikan berkorelasi dengan niat menggunakan sistem perdagangan online. Serupa studi telah dilakukan oleh Luarn dan Lin (2005), dimana mereka menemukan bahwa ada pengaruh positif antara persepsi kemudahan penggunaan dan niat penggunaan.

Konsumen umumnya terlibat dalam analisis "biaya-manfaat" saat memilih pengambilan keputusanprosedur Wright (1975), jauh sebelum internet diketahui. Selanjutnya, dalam belajarmobile banking telah menyarankan agar pelanggan mempertimbangkan kognitif dan afektifevaluasi dalam membeli produk dan ini adalah bagian dari manfaat hedonistik Kim, Chan, \& Gupta (2007). Sejalan dengan itu, manfaat yang dirasakan ditemukan sebagai faktor penting dalam memahami perbankan online Lee mengetahui bahwa niat untuk menggunakan perbankan online dan dipengaruhi oleh manfaat yang dirasakan.

Sikap mengacu pada efek evaluatif positif atau evaluatif negatif tentang melakukan perilaku tertentu dalam hal mobile banking, kebanyakan pelanggan terpapar arusteknologi yang akan melibatkan mereka melakukan transaksi bisnis online. Menurutstudi empiris sebelumnya telah menunjukkan adanya sikap menggeneralisasi seperti itupengaruh pada evaluasi teknologi baru (Norazah \& Norbayah,2009; Norazah, Ramayah, \& Norbayah, 2008).Dalam penelitian ini, sikap dihipotesiskan terhadap pengaruh niat perilaku untuk digunakan Mobile banking dan juga menengahi hubungan antara variabel independen (persepsikegunaan, persepsi kemudahan penggunaan, persepsi benefit, persepsi kredibilitas dan persepsibiaya keuangan) dan variabel dependen (niat perilaku untuk menggunakan mobile banking).

Oleh karna itu dalam penelitian ini diajukan hipotesis sebagai berikut:

H4 :Perceived usefulness berpengaruh positif terhadap Behavioral Intention.

H5 :Perceived ease of use berpengaruh positif terhadap Behavioral Intention.

H6 : Perceived risk berpengaruh positif terhadap Behavioral Intention. H7 : Sikap terhadap M-banking berpengaruh positif terhadap Behavioral Intention. 


\section{Model Empirik Penelitian}

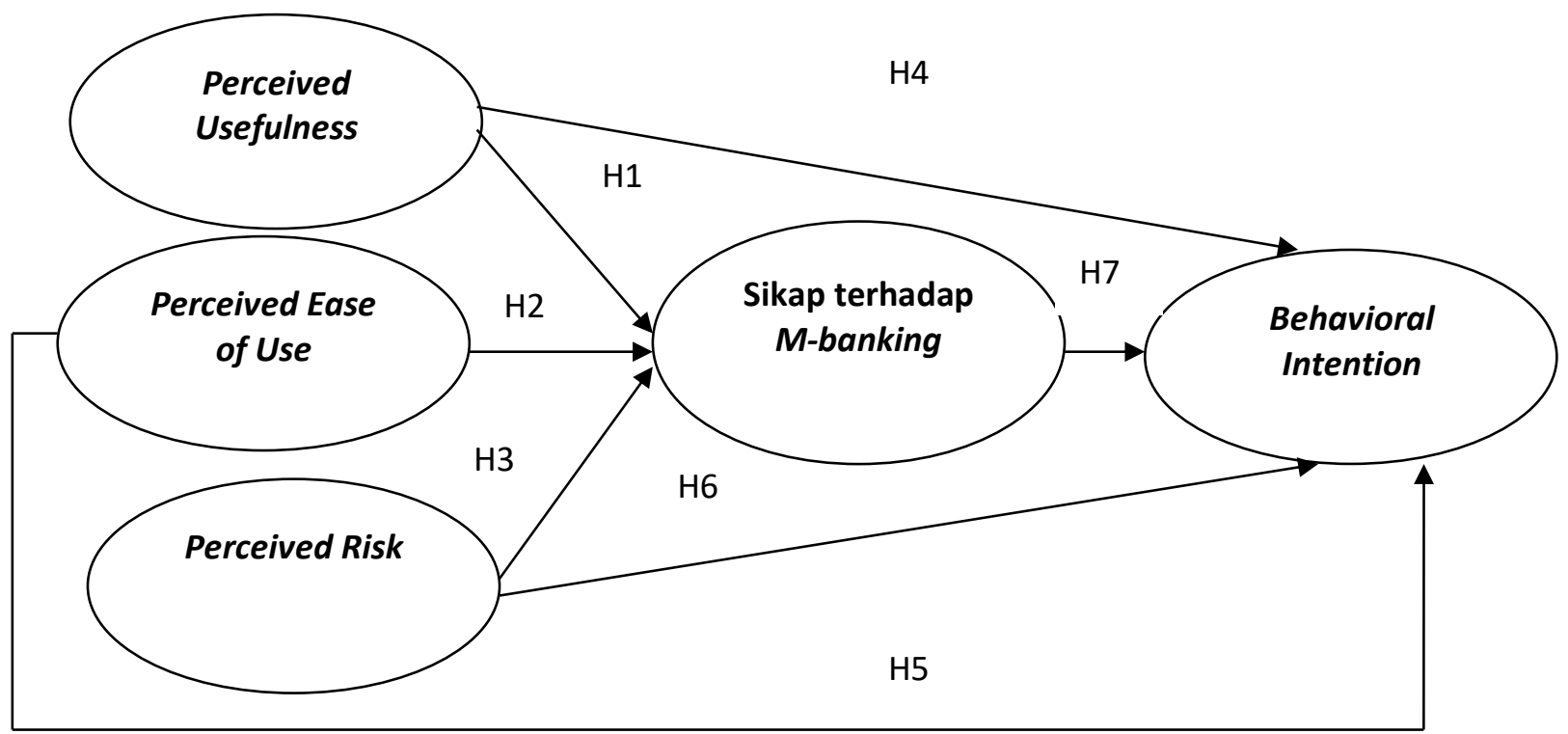

Gambar 1

Kerangka Pemikiran Teoritis

\section{METODE PENELITIAN}

Populasi

Dalam penelitian populasi yang diambil adalah nasabah Bank Syariah Mandiri Kota Semarang.

\section{Sampel}

Dalam penelitian ini pengambilan sampel dilakukan dengan menggunakan teknik convenience sampling, dengan kriteria: Telah menggunakan jasa lebih dari 3 tahun dan Berumur lebih dari 17 tahun.

\section{Uji Validitas}

Validasi menunjukan sejauh mana suatu alat ukur itu mengukur construct yang akan diukur. Pengujian homogenitas dilakukan untuk menguji analisis validasi tersebut. Untuk pertanyaan yang digunakan dalam mengukur suatu variabel, skor masing-masing item dikorelasikan dengan total skor item dalam satu variabel. Jika skor item tersebut berkorelasi positif dengan total skoritem dan lebih tinggi dari interkorelasi antar item, maka menunjukan kavalidan dari instrumen tersebut. Korelasi ini dilakukan dengan menggunakan metode korelasi Product Moment Pearson. Singgih (2000) Suatu alat ukur dikatakan valid jika Corrected item total correlation lebih besar atau sama dengan 0,05

\section{Uji Reliabilitas}

Uji reabilitas adalah ukuran konsistens instrumen penelitian. Instrumen dikatakan reliabel jika alat ukur tersebut menunjukan hasil yang konsisten, sehingga instrumen ini dapat digunakan dengan aman karena dapat bekerja dengan baik pada waktu dan kondisi yang berbeda Cooper dan Emory (1995). Dalam penelitian ini peneliti melakukan uji realibilitas dengan menggunakan Crobach Alpha. Suatu instrumen dapat disebut reliabel apabila memiliki Crobach Alpha lebih besar dari 0,60. Untuk menghitung realibilitas variabel digunakan bantuan program 
SPSS 10.0 for windows.

\section{Uji Multikolonieritas}

Uji Multikolonieritas mempunyai tujuan untuk menguji apakah dalam model regresi ditemukan adanya korelasi antar variabel bebas Ghozali (2009). Multikolonieritas dideteksi dengan menggunakan nilai Tolerance dan Variance Inflantion Factor (VIF). Tolerance mengukur variabilitas variabel bebas yang terpilih yang tidak dapat dijelaskan oleh variabel bebas lainnya. Jadi nilai tolerance yang rendah sama dengan nilai VIF yang tinggi (karena VIF $=1 /$ tolerance) dan menunjukkan adanya kolonearitas yang tinggi. Nilai cutoff yang umum dipakai adalah nilai tolerance 0,10 atau sama dengan nilai VIF di bawah 10 .

\section{Uji Normalitas}

Uji Normalitas adalah pengujian tentang kenormalan distribusi variabel terikat dan variabel bebas dalam model regresi. Uji normalitas bertujuan untuk mengetahui apakah dalam model regresi, variabel terikat dan variabel bebas memiliki distribusi normal atau tidak, karena model regresi yang baik memiliki distribusi data yang normal atau yang mendekati normal. Model regresi yang baik harus memiliki distribusi data normal atau penyebaran data statistik pada sumbu diagonal dari grafik distribusi normal Ghozali (2009).

\section{Uji Heteroskedastisitas}

Uji Heteroskedastisitas bertujuan untuk mengetahui apakah dalam model regresi terjadi ketidaksamaan variance dari residual satu pengamatan ke pengamatan yang lain. Jika variance dari residual satu pengamatan ke pengamatan yang lain tetap maka disebut homoskedastisitas, namun jika berbeda disebut heteroskedastisitas.

\section{Uji Hipotesis}

Metode analisis yang digunakan uji hipotesis dalam penelitian ini analisis jalur (path analysis) yang digunakan untuk mengecak model hubungan yang telah ditentukan bukan untuk menemukan penyebabnya. Analisis jalur dapat dilakukan estimasi besarnya hubungan kausal antara sejumlah variabel dan hierarki kedudukan masing-masing variabel dalam rangkaian jalur-jalur kausal, baik secara langsung maupun tidak langsung.

\section{Uji t}

Uji t digunakan untuk menguji tingkat signifikan melalui t dengan membandingkan $\mathrm{t}$ hitung (observasi) dengan tingkat signifikasnis $(\alpha)=0,05$ ditentukan sebagai berikut :

a. thitung $<\mathrm{t}$ tabel, atau sig $\mathrm{T}<0,05$ maka $\mathrm{H}_{0}$ ditolak.

b. thitung $>t_{\text {tabel, }}$ atau sig $\mathrm{T}>0,05$ maka $\mathrm{H}_{0}$ diterima.

\section{Uji F}

Uji F yaitu suatu uji untuk menegetahui pengaruh variabel bebassecara simultan terhadap varibel terikat. Kriteria untuk menguji hipotesis adalah:

a. Membuat hipotesis untuk kasus pengujian F-test di atas, yaitu:

- $\mathrm{H}_{0}: \mathrm{b}_{1}=\mathrm{b}_{2}=\mathrm{b}_{3}=\mathrm{b}_{4}=0$

- $\mathrm{H}_{0}: \mathrm{b}_{1}-\mathrm{b}_{4}>0$

b. Menentukan F tabel dan F hitung. Dengan tingkat kepercayaan sebesar 95\% atau taraf signifikan sebesar 5\%, maka:

- Jika Fhitung $>$ Ftabel, atau sig $\mathrm{F}<0,05$ maka $\mathrm{H}_{0}$ ditolak.

- Jika F hitung $<\mathrm{F}_{\text {tabel, }}$ atau sig $\mathrm{F}>0,05$ maka $\mathrm{H}_{0}$ diterima. 


\section{Uji Determinasi}

Koefisien determinasi pada intinya mengukur seberapa jauh kemampuan model dalam menerangkan variasi variabel dependen Ghozali (2009). Nilai koefisien determinasi adalah antara nol dan satu. Nilai R2 yang kecil berarti kemampuan variabel-variabel independen dalam menjelaskan variasi variabel dependen amat terbatas. Nilai yang mendekati satu berarti variabel-variabel independen memberikan hampir semua informasi yang dibutuhkan untuk memprediksi variasi variabel dependen.

\section{HASIL DAN PEMBAHASAN}

\section{Uji Validitas}

\begin{tabular}{cccccc}
\hline \multirow{2}{*}{ Variabel } & $\begin{array}{c}\text { Indik } \\
\text { ator }\end{array}$ & $\alpha$ & $\begin{array}{c}\mathrm{R} \\
\text { Tabel }\end{array}$ & $\begin{array}{c}\mathrm{R} \\
\text { Hitung }\end{array}$ & Ket \\
\hline Behavioral & $\mathrm{Y} 2.1$ & 0,05 & 0,197 & 0,472 & Valid \\
Intention (Y) & $\mathrm{Y} 2.2$ & 0,05 & 0,197 & 0,526 & Valid \\
& $\mathrm{Y} 2.3$ & 0,05 & 0,197 & 0,745 & Valid \\
\hline Perceived & $\mathrm{X} 1.1$ & 0,05 & 0,197 & 0,751 & Valid \\
usefulness $\left(\mathrm{X}_{1}\right)$ & $\mathrm{X} 1.2$ & 0,05 & 0,197 & 0,781 & Valid \\
& $\mathrm{X} 1.3$ & 0,05 & 0,197 & 0,854 & Valid \\
& $\mathrm{X} 1.4$ & 0,05 & 0,197 & 0,462 & Valid \\
& $\mathrm{X} 1.5$ & 0,05 & 0,197 & 0,743 & Valid \\
\hline Perceived ease of & $\mathrm{X} 2.1$ & 0,05 & 0,197 & 0,608 & Valid \\
Use (X2) & $\mathrm{X} 2.2$ & 0,05 & 0,197 & 0,552 & Valid \\
& $\mathrm{X} 2.3$ & 0,05 & 0,197 & 0,624 & Valid \\
& $\mathrm{X} 2.4$ & 0,05 & 0,197 & 0,590 & Valid \\
& $\mathrm{X} 2.5$ & 0,05 & 0,197 & 0,429 & Valid \\
& $\mathrm{X} 2.6$ & 0,05 & 0,197 & 0,203 & Valid \\
& $\mathrm{X} 2.7$ & 0,05 & 0,197 & 0,681 & Valid \\
\hline Perceived risk & $\mathrm{X} 3.1$ & 0,05 & 0,197 & 0,827 & Valid \\
(X) & $\mathrm{X} 3.2$ & 0,05 & 0,197 & 0,589 & Valid \\
& $\mathrm{X} 3.3$ & 0,05 & 0,197 & 0,647 & Valid \\
& $\mathrm{X} 3.4$ & 0,05 & 0,197 & 0,827 & Valid \\
\hline Sikap terhadap M- & $\mathrm{Y} 1.1$ & 0,05 & 0,197 & 0,253 & Valid \\
Banking (X 4 ) & $\mathrm{Y} 1.2$ & 0,05 & 0,197 & 0,800 & Valid \\
& $\mathrm{Y} 1.3$ & 0,05 & 0,197 & 0,641 & Valid \\
& $\mathrm{Y} 1.4$ & 0,05 & 0,197 & 0,800 & Valid \\
\hline
\end{tabular}

Dari hasil uji validitas dapat dikatakan bahwa keseluruhan pernyataan yang diajukan oleh peneliti terhadap responden valid karena nilai $r$ hitung $>\mathrm{r}$ tabel.

\section{Uji Reliabilitas}

\begin{tabular}{lccc}
\hline \multicolumn{1}{c}{ Variabel } & $\begin{array}{c}\text { cronbach's } \\
\text { alpha }\end{array}$ & $\begin{array}{c}\text { Standar } \\
\text { alpha }\end{array}$ & Keterangan \\
\hline Perceived usefulness & 0,881 & 0,60 & Reliabel \\
Perceived ease of Use & 0,792 & 0,60 & Reliabel \\
Perceived risk & 0,867 & 0,60 & Reliabel \\
Sikap terhadap $M-$ & 0,775 & 0,60 & Reliabel \\
\hline
\end{tabular}


Banking

Behavioral Intention $\quad 0,743 \quad 0,60 \quad$ Reliabel

Berdasarkan hasil uji reliabilitas semua variabel dikatakan reliabel sehingga layak untuk diujikan ke pengujian hipotesis selanjutnya.

\section{Uji Normalitas}

Berdasarkan uji normalitas, dapat diketahui bahwa titik-titik menyebar di sepanjang garis diagonal dan mendekati garis diagonal. Dengan demikian model regresi dalam penelitian ini adalah normal.

\section{Uji Multikolinearitas}

\begin{tabular}{llll}
\multicolumn{3}{c}{ Coefficients $^{\text {a }}$} \\
\hline & & \multicolumn{2}{c}{ Collinearity Statistics } \\
\cline { 3 - 4 } Model & & Tolerance & VIF \\
\hline 1 & & & \\
& & (Constant) & \\
& Perceived Usefulness & .748 & 1.337 \\
& Perceived Ease of Use & .856 & 1.168 \\
& Perceived Risk & .658 & 1.519 \\
\hline
\end{tabular}

Hasil uji multikolinearitas menunjukkan bahwa semua variabel independen mempunyai nilai tolerance lebih besar dari $10 \%(0,10)$ dan nilai VIF lebih kecil dari 10 sehingga dapat disimpulkan tidak terjadi multikolinearitas.

\section{Uji Heterokedastisitas}

Dari uji heteroskedastisitas dapat diketahui bahwa data menyebar (tidak terdapat deviasi standar antara variabel bebas terhadap variabel dan tidak membentuk pola tertentu, sehingga tidak terjadi heteroskedastisitas.

\section{Uji Regresi Berganda}

Persamaan I

\section{Coeffieients}

\begin{tabular}{|c|c|c|c|c|c|}
\hline \multirow[b]{2}{*}{ Model } & \multicolumn{2}{|c|}{$\begin{array}{l}\text { Unstandardized } \\
\text { Coefficients }\end{array}$} & \multicolumn{2}{|c|}{$\begin{array}{l}\text { Standardized } \\
\text { Coefficients }\end{array}$} & \multirow[b]{2}{*}{ Sig. } \\
\hline & B S & td. Erro & Beta & $\mathrm{t}$ & \\
\hline (Constant) & 3.524 & 1.599 & & 2.204 & .030 \\
\hline Perceived Usefuln & 165. ר & .053 & .280 & 3.121 & .002 \\
\hline Perceived Ease of & .263 & .051 & .430 & 5.140 & .000 \\
\hline Perceived Risk & .137 & .066 & .197 & 2.064 & .042 \\
\hline
\end{tabular}

Hasil persamaan regresi berganda tersebut memberikan pengertian bahwa:

a. Nilai koefisien regresi perceived usefulness, sebesar 0,280 bernilai positif, dapat diartikan bahwa apabila perceived usefulness semakin meningkat, maka sikap terhadap M-Banking 
semakin meningkat, seperti nasabah merasa $M$-Banking adalah pilihan yang baik, cerdik, dan bijak

b. Nilai koefisien regresi perceived ease of Use, sebesar 0,430bernilai positif, dapat diartikan bahwa apabila perceived ease of Use semakin meningkat, maka sikap terhadap M-Banking semakin meningkat, seperti nasabah merasa $M$-Banking adalah pilihan yang baik, cerdik, dan bijak

c. Nilai koefisien regresi perceived risk, sebesar 0,197 bernilai positif, dapat diartikan bahwa apabila perceived risk semakin meningkat, maka sikap terhadap M-Banking semakin meningkat, seperti nasabah merasa M-Banking adalah pilihan yang baik, cerdik, dan bijak

Persamaan II

\begin{tabular}{lccccc}
\multicolumn{6}{c}{ Coeffieients } \\
\hline \multicolumn{5}{c}{$\begin{array}{l}\text { Unstandardized Standardized } \\
\text { Coefficients }\end{array}$} & \multicolumn{1}{c}{ Coefficients } \\
\cline { 2 - 5 } Model & B Std. Erro & Beta & $\mathrm{t}$ & Sig. \\
\hline Sikap Terhadap M & .468 & .036 & .634 & 12.823 & .000 \\
Perceived Usefuln & .052 & .020 & .125 & 2.735 & .007 \\
Perceived Ease of & .094 & .021 & .205 & 4.466 & .000 \\
Perceived Risk & .100 & .024 & .196 & 4.146 & .000 \\
\hline Dependent Variable: Behavioral Intention
\end{tabular}

Hasil persamaan regresi berganda tersebut memberikan pengertian bahwa:

a. Nilai koefisien regresi perceived usefulness, sebesar 0,125 bernilai positif, dapat diartikan bahwa apabila perceived usefulness semakin meningkat, maka Behavioral Intention semakin meningkat.

b. Nilai koefisien regresi perceived ease of Use, sebesar 0,205 bernilai positif, dapat diartikan bahwa apabila perceived ease of Use semakin meningkat, maka Behavioral Intention semakin meningkat.

c. Nilai koefisien regresi perceived risk, sebesar 0,196 bernilai positif, dapat diartikan bahwa apabila perceived risk semakin meningkat, maka Behavioral Intention semakin meningkat.

d. Nilai koefisien regresi sikap terhadap $M$ - Banking, sebesar 0,634 bernilai positif, dapat diartikan bahwa apabila sikap terhadap M-Banking semakin meningkat, maka Behavioral Intention semakin meningkat.

\section{Uji Koefisien Determinasi}

\begin{tabular}{|c|c|c|c|c|}
\hline \multicolumn{5}{|c|}{ Model Summary } \\
\hline Model & $\mathrm{R}$ & R Square & $\begin{array}{l}\text { Adjusted } \\
\text { R Square }\end{array}$ & $\begin{array}{l}\text { Std. Error of } \\
\text { the Estimate }\end{array}$ \\
\hline 1 & $.931^{a}$ & .866 & .860 & .572 \\
\hline
\end{tabular}

Koefisien determinasi digunakan untuk mengetahui seberapa besar variabilitas variabel independen dalam menjelaskan variabel dependen yang ditunjukkan oleh nilai $\mathrm{R}$ square $\left(\mathrm{R}^{2}\right)$ yaitu sebesar 0,860 artinya variabilitas variabel Perceived usefulness, Perceived ease of Use, Perceived risk mampu menjelaskan Behavioral Intention (Y) sebesar 86,0 \%, sisanya sebesar $14,0 \%$ dijelaskan oleh variabilitas variabel lain yang tidak diteliti dalam penelitian ini. 


\section{Uji Hipotesis}

\begin{tabular}{cccc}
\hline Hipotesis & t hitung & Lebih besar & t tabel \\
\hline H1 & & & \\
\hline H2 & 5,140 & $>$ & 1,985 \\
\hline H3 & 2.064 & $>$ & 1,985 \\
\hline H4 & 2,735 & $>$ & 1,985 \\
\hline H5 & 4,466 & $>$ & 1,985 \\
\hline H6 & 4,146 & $>$ & 1,985 \\
\hline H7 & 12,823 & $>$ & 1,985 \\
\hline
\end{tabular}

Semua Hipotesis nilai t hitung lebih besar daripada nilai t tabel.

\section{Pengaruh Langsung dan Tidak Langsung}

Nilai pengaruh langsung perceived usefulnessterhadap behavioral intention sebesar 0,125 lebih kecil dibandingkan dengan pengaruh tidak langsung sebesar $0,177 \quad(0,280 \times 0,634)$, dengan demikian dalam penelitian ini perceived usefulness berpengaruh tidak langsung terhadap behavioral intention melalui sikap terhadap M-Banking. Dengan demikian sikap terhadap M-Banking merupakan variabel intervening di antara pengaruh perceived usefulness dengan behavioral intention. Hal ini mengindikasikan bahwa perceived usefulness yang dilakukan oleh perusahaan akan membuat sikap yang baik nasabah, sehingga akan meningkatkan niat nasabah untuk setia pada perusahaan.

Nilai pengaruh langsung perceived ease of use terhadap behavioral intention sebesar 0,205 lebih kecil dibandingkan dengan pengaruh tidak langsung sebesar $0,272(0,280 \times 0,634)$, dengan demikian dalam penelitian ini perceived ease of useberpengaruh tidak langsung terhadap behavioral intention melalui sikap terhadap M-Banking. Dengan demikian sikap terhadap M-Banking merupakan variabel intervening di antara pengaruh perceived ease of use dengan behavioral intention. Hal ini mengindikasikan bahwa perceived ease of use yang dilakukan oleh perusahaan akan membuat sikap yang baik nasabah, sehingga akan meningkatkan niat nasabah untuk setia pada perusahaan dan merekomendasikan pada orang lain.

\section{PEMBAHASAN}

\section{Pengaruh Perceived Usefulness terhadap Sikap terhadap M-banking}

Perceived usefulness berpengaruh positif terhadap sikap terhadap M-banking. artinya apabila perceived usefulness semakinbaik, yaitu membantu dalam menyelesaikan pekerjaan,menggunakan mbanking akan sangat fleksibel untuk bertransaksi kapan saja, kemudahan dalam menerima layanan, memiliki banyak manfaat, dan mampu mengendalikan aktivitas transaksi dengan lebih baik. Maka akan semakin baik Sikap terhadap $m$-banking yaitu menggunakan $m$-banking merupakan pilihan yang baik, menggunakan $m$-banking menjadi pemikiran yang bijak, menggunakan $m$-banking merupakan pilihan yang cerdik, dan dengan menggunakan mbanking tidak perlu berpikir dua kali untuk menggunakan transaksi tersebut.

Kegunaan yang dirasakan telahdikonfirmasi yang dapat menjadi penting dalam mempengaruhi niat dan penggunaan oleh penelitian ekstensif di masa lalu. Ada juga bukti empiris yang luas yang mendukung pengaruh signifikan dari perceived usefulness terhadap niat 
perilaku (misalnya Davis et al., 1989; Jackson et al., 1997; Venkatesh, 1999).

\section{Pengaruh Perceived Ease Of Use terhadap Sikap terhadap M-banking}

Perceived Risk berpengaruh terhadap sikap terhadap M-banking. Hal ini menunjukkan bahwa resiko yang tinggi akan mempengaruhi niat nasabah dalam menggunakan mobile banking karena resiko dipandang sebagai ketidakpastian yang dihubungkan dengan hasil dari suatu keputusan.Hal ini juga berarti bahwa nasabah khawatir dalam menggunakan mobile banking akan ada resiko tertentu. Resiko bisa datang dari sistem maupun dari nasabah tersebut, resiko dari sistem kendalanya ada pada signalatau jaringan internet yang digunakan karena apabila saat bertransaksi signalatau jaringan internetnya tidak bagus akan mempengaruhi transaksi tersebut. Risiko dari pengguna atau nasabah apabila nasabah kehilangan handphone yang digunakan untuk bertransaksi.

Berdasarkan hasil penelitian ini konsisten dengan penelitian Farizi dan Syaefullah (2013), Safeena et al (2009), Widyarini dan Putro (2008), Saraswati dan Baridwan (2012), yang menyatakan bahwa persepsi resiko mempunyai pengaruh terhadap penggunaan internet banking

\section{Pengaruh Perceived Usefulness terhadap Behavioral Intention}

Perceived usefulness berpengaruh positif terhadap Behavioral intention. artinya apabila perceived usefulness semakin baik, yaitu membantu dalam menyelesaikan pekerjaan,menggunakan mbanking akan sangat fleksibel untuk bertransaksi kapan saja, kemudahan dalam menerima layanan, memiliki banyak manfaat, dan mampu mengendalikan aktivitas transaksi dengan lebih baik, maka behavioral intention yaitu tetap menggunakan mbanking dengan jangka panjang, menggunakan mbanking untuk semua tujuan, dan akan merekomendasikan pengguna mbanking kepada orang lain semakin meningkat.

Menurut Novi (2003) persepsi kemudahan penggunaan didefinisikan sebagai penilaian seseorang mengenai suatu teknologi bahwa tidak perlu kemampuan yang tinggi untuk menggunakannya, ada beberapa indikator kemudahan penggunaan teknologi informasi antara lain meliputi: Teknologi informasi sangat mudah dipelajari, teknologi informasi mengerjakan dengan mudah apa yang diinginkan oleh pengguna, ketrampilan pengguna akan bertambah dengan menggunakan teknologi informasi, dan teknologi informasi sangat mudah untuk dioperasikan. Beberapa penelitian terdahulu menunjukkan bahwa persepsi kemudahan merupakan faktor utama yang berpengaruh terhadap sikap positif penggunaan layanan mobile banking.

\section{Pengaruh Perceived Ease Of Use terhadap Behavioral Intention}

Perceived ease of use berpengaruh positif terhadap Behavioral intention, artinya apabila perceived ease of use semakin baik yaitu menggunakan mbanking sangat mudah, menggunakan mbanking sangat mudah untuk difahami, proses dalam menggunakan mbanking akan mudah diingat, percaya bahwa antar muka dari mbanking mudah dimengerti, kemudahan penggunaan mbanking, mahir dalam menggunakan mbanking, menggunakan mbanking sangat mudah untuk dimengerti, maka behavioral intention yaitu tetap menggunakan mbanking dengan jangka panjang, menggunakan mbanking untuk semua tujuan, dan akan merekomendasikan pengguna mbanking kepada orang lain semakin meningkat.

Serupa studi telah dilakukan oleh Luarn dan Lin (2005), dimana mereka menemukan bahwa ada pengaruh positif antara persepsi kemudahan penggunaan dan niat penggunaan. 


\section{Pengaruh Perceived Risk terhadap Behavioral Intention}

Perceived risk berpengaruh positif terhadap Behavioral Intention, artinya apabila perceived risk semakin meningkat yaitu menggunakan mbanking sangat aman, memiliki privasi sendiri saat menggunakan internet layanan perbankan, dengan menggunakan mbanking privasi sangat terjaga, ada kemungkinan akan hadapi masalah saat melakukan transaksi melalui internet, maka behavioral intention yaitu tetap menggunakan mbanking dengan jangka panjang, menggunakan mbanking untuk semua tujuan, dan akan merekomendasikan pengguna mbanking kepada orang lain semakin meningkat.

Perceived Risk berpengaruh terhadap Behavioral Intention. Nasabah umumnya terlibat dalam analisis "biaya-manfaat" saat memilih pengambilan keputusan prosedur Wright (2000), jauh sebelum internet diketahui. Selanjutnya, dalam belajar mobile banking telah menyarankan agar pelanggan mempertimbangkan kognitif dan afektifevaluasi adalah bagian dari manfaat hedonistik (Kim, Chan, \& Gupta, 2007). Sejalan dengan itu, manfaat yang dirasakan ditemukan sebagai faktor penting dalam memahami perbankan online Lee (2009) mengetahui bahwa niat untuk menggunakan perbankan onlinedan positif dipengaruhi oleh manfaat yang dirasakan.

Pengaruh Sikap terhadap M-banking terhadap Behavioral Intention

Sikap terhadap M-banking berpengaruh positif terhadap Behavioral Intention, artinya apabila sikap terhadap M-banking semakin meningkat yaitu menggunakan $m$ bankingmerupakan pilihan yang baik, menggunakan $m$-banking menjadi pemikiran yang bijak, menggunakan m-banking merupakan pilihan yang cerdik, dan dengan menggunakan mbankingtidak perlu berpikir dua kali untuk menggunakan transaksi tersebut,maka behavioral intention yaitu tetap menggunakan mbanking dengan jangka panjang, menggunakan mbanking untuk semua tujuan, dan akan merekomendasikan pengguna mbanking kepada orang lain semakin meningkat.

Sikap terhadap M-banking berpengaruh terhadap Behavioral intention. Dalam penelitian ini, sikap dihipotesiskan terhadap pengaruh niat perilaku untuk digunakan Mobile banking dan juga menengahi hubungan antara variabel independen (persepsi kegunaan, persepsi kemudahan penggunaan, persepsi benefit, persepsi kredibilitas dan persepsibiaya keuangan) dan variabel dependen (niat perilaku untuk menggunakan mobile banking).

\section{Sikap Terhadap M-banking sebagai Variabel Intervening}

Sikap terhadap M-banking merupakan variabel intervening antara perceived usefulness terhadap behavioral intention dan juga antara perceived ease of use terhadap behavioral intention. Hal ini bisa dipahami karena dengan sikap mbanking yang baik seperti $M$-banking adalah pilihan yang baik, bijak, cerdik, dan tidak perlu berpikir dua kali untuk melakukan transaksi maka akan menciptakan behavioral intention yang baik. Jadi apabila perusahaan ingin meningkatkan behavioral intention alangkah lebih baik harus meningkatkan terlebih dahulu Sikap terhadap M-banking.

\section{PENUTUP}

Berdasarkan penelitian yang telah dilakukan, maka dapat dibuat kesimpulan sebagai berikut :

Perceived usefulness berpengaruh terhadap sikap terhadap M-banking dengan arah regresi signifikan dan positif, artinya apabila semakin tinggi Perceived usefulness maka sikap terhadap M-banking semakin meningkat. 
Perceived ease of use berpengaruh terhadap sikap terhadap M-banking dengan arah regresi signifikan dan positif, artinya apabila semakin tinggi Perceived ease of use maka sikap terhadap M-banking semakin meningkat.

Perceived risk berpengaruh terhadap sikap terhadap M-banking dengan arah regresi signifikan dan positif, artinya apabila semakin tinggi Perceived risk maka sikap terhadap $M$ banking semakin meningkat.

Perceived usefulness berpengaruh terhadap Behavioral intention, dengan arah regresi signifikan dan positif, artinya apabila semakin tinggi Perceived usefulness maka Behavioral intention akan semakin meningkat.

Perceived ease of use berpengaruh terhadap Behavioral intention dengan arah regresi signifikan dan positif, artinya apabila semakin tinggi Perceived ease of use maka Behavioral intention semakin meningkat.

Perceived risk berpengaruh terhadap Behavioral intention dengan arah regresi signifikan dan positif, artinya apabila semakin tinggi Perceived risk maka Behavioral intention semakin meningkat.

Sikap terhadap M-banking berpengaruh terhadap Behavioral intention dengan arah regresi signifikan dan positif, artinya apabila semakin tinggi Sikap terhadap M-banking maka Behavioral intention semakin meningkat.

Sikap terhadap M-banking merupakan variabel intervening antara perceived usefulness terhadap behavioral intention dan juga antara perceived ease of use terhadap behavioral intention. Hal ini bisa dipahami karena dengan sikap mbanking yang baik seperti $M$-banking adalah pilihan yang baik, bijak, cerdik, dan tidak perlu berpikir dua kali untuk melakukan transaksi maka akan menciptakan behavioral intention yang baik.

\section{REFERENSI}

Assael, Henry. (2014). Consumer Behavior 6th Edition. New York : Thomson-Learning. Azwar, Saifuddin.( 2003). Reliabilitas dan Validitas. Yogyakarta : Pustaka Pelajar.

Chin, W.C. dan Todd, P.A. 2011. On the Use, Usefulness and Ease of UseofStructural Equation Modelling in MIS Research: A Note of Caution. MIS Quarterly, Vol. 19 No.237-46.

Cooper, D R, And Emory, C W. 1995, Business Research Methods, 5thedition,Richard D. Irwin Inc.

Davis, F. D. (1989). Perceived Usefulness, Perceived Ease of Use, and User Acceptance of Information Technology. MIS Quarterly, 13(3), 319-340. doi: 10.2307/249008.

Dharmmesta, Basu Swastha. 1998 Loyalitas Pelanggan : Sebuah Kajian Konseptual Sebagai Panduan Bagi Peneliti. Jurnal Ekonomi dan Bisnis Indonesia, Vol.14, No. 3, Tahun1999.

Farizi, Syaefullah,MM,Akt. 2013. "Pengaruh Persepsi Kegunaan, Persepsi Kemudahan, Persepsi Resiko, dan Kepercayaan terhadap Minat menggunakan Internet Banking”. Jurnal Akuntansi Universitas Brawijaya Malang.

Fishbein, M. and Azjen, I. (2005). Belief, Attitude, Intention, and Behavior: An Introduction to Theory and Research. Addison - Wesely, Boston MA.

Ghozali, Imam. 2009. "Aplikasi Analisis Multivariate dengan Program SPSS “. Semarang : UNDIP.

Guriting P, Ndubisi NO (2006). "Borneo online banking:evaluatingcustomer perceptions and behavioural intention".Manage. Res. News. 29 (1/2), 6-15.

Jackson et al, (1997). "Pengaruh Persepsi Kegunaan, Persepsi Kemudahan Penggunaan, Persepsi Kesesuaian, dan Persepsi Resiko terhadap Sikap Penggunaan Mobile Banking”. 
Jurnal Akuntansi Universitas Brawijaya Malang.

Jacoby, J. and Kaplan, L.B. 1972. The component of perceived risk. 3rd. Annual Conference Of the Association For Costumer Research, Association For Consumer Research, pp. 382-293.

Jogiyanto, H.M. (2007). Sistem Informasi Keperilakuan. Yogyakarta: Andy.

Karahanna,E. \& Straub, D.W. (1999). Trust and TAM in Online Shopping: An Integrated Model.Management InformationSystem Quarterly,27(1): 51-90.

Katz, E., Blumer J. G. Dan Gurevitch, M. 1974. 'Utilization of mass communication by the individual,' dalam J.G. Blumer dan E. Katz (eds), The Uses of Mass Communication. Baverly Hills: Sage.

Kim, H. W., Chan, H. C. \& Gupta, S. Y. The effects of post-adoption beliefs on the expectationconfirmation model for informationtechnology continuance. Decision Support Systems, vol. 43, no.1 . (2007).

Kotler, Philip (2006). Manajemen Pemasaran, Edisi Pertama. Indonesia : PT. Indeks Kelompok Gramedia

Kusuma, Hadri.,dan Susilowati. (2007). Determinan Pengadopsian Layanan Internet Banking: Perspektif Konsumen Perbankan Daerah Istimewa Yogyakarta, Jurnal Akuntasi dan Auditing Indonesia, Desember, Vol. 11, No. 2, pp. 125-139

Lau, Gale dan Lee, S. (2002). Costumer Trust in a Brand and Link to Brand Loyalty. Journal of Market Focused Management, vol 4, pp. 341-70.

Lee, Hee Seo; Kim, Taek Gyeom;Choi, Ji Youn, “A Study on the Factors Affecting SmartPhone Application Acceptance”, Singapore, (2009).

Lin C. B., \& Wan, G. (2008). Including Subjective Norm and Technology Trust in the Technology Acceptance Model: A Case of E-Ticketing in China. 41 (4).

Luarn P. And HH. Lin (2005), "A Customer Loyalty Model for E-Service Context, “ Jurnal of Electronic Commerce Resarch, Vo1.4, No. 4,pp. 156-167.

Norazah, M. S., \& Norbayah, M. S. (2009). Exploring the relationship between perceived usefulness, perceived ease of use, perceived enjoyment, attitude and subscribers' intention towards using $3 G$ mobile service. Internet Journal, 3(3), 1-11.

Norazah, M. S., Ramayah, T., \& Norbayah, M. S. (2008). Internet shopping acceptance: Examining the influence of intrinsic versus extrinsic motivations. Direct Marketing: An International Journal, 2(2), 97-110. doi:10.1108/17505930810881752

Noto atmodjo, s. (2003).Pendidikan dan perilaku kesehatan,Jakarta : PT RinekaCipta.

Novi, (2003),"Faktor- faktor yang Mempengaruhi Penggunaan Layanan Mobile Banking", jurnal optimum vol 5, no 1

Oglethorpe, J. E and Monroe, B. K., (2014)), Determinant of Perceived Health and Safety Risk of Selected Hazardous Product and Activities, Journal of Consumer Research, No.28.

Robey D. User. (1979). Attitudes and Management Information System Use. Academy of Management Journal.

Roselius, T. (1971), "Consumer rankings of risk reduction methods", Journal of Marketing, Vol. 35 No. 1 , pp. 56 - 61.

Saraswati, dan Baridwan. (2012). "Penerimaan Sistem E-Comemerce: Pengaruh Kepercayaan, Persepsi Manfaat dan Persepsi Resiko". Jurnal Akuntansi. Universitas Brawijaya Malang.

Safeena et al. (2009). Impact of Service Quality, Trust, and Customer Satisfaction Loyalty, ABAC Journal, Vol. 29, No.1.Januari, 24-38. 
Singgih Santoso. 2000. Latihan SPSS Statistik Parmetik. Gramedia, Jakarta.

Schultz dan Slevin. (1975). Implementation and Organizational Validity : An empiricalInvestigation. Implementating Operation Research Management Science. NewYork. 1975.

Sihombing, dan Hauser, (2004). Disertasi Hubungan Sikap dan Perilaku Memilih Satu Merek: Komparasi antara Theory of Planed Behavior dan Theory of Trying. Universitas Gadjah mada yogyakarta.

Tjayono ,Ayub Willianto. Paskah Ika Nugroho (2010). Pengaruh manfaat dan kemudahan penggunaan terhadap sikap positif penggunaan Internet banking : sruvey pda pengguna klik BCA di Semarang. Jurnal bisnis dan ekonomi. Universitas Muhammadiyah Magelang. Pusat Pengembangan Akuntansi.

Venkatesh, (1999). User Acceptance Of Information Technology: Toward a Unified View. MIS Quertely. Volume 27(3), pp.425-478.

Wibowo, A. (2008). Kajian Tentang Perilaku Pengguna Sistem Informasi Dengan Pendekatan Technology Acceptance Model (TAM). Program Studi Sistem Informasi. Fakultas Teknologi Informasi. Universitas Budi Luhur.

Widyarini dan Putro. (2008). "Analisis Hubungan Faktor-Faktor Technology, Acceptance, Trust dan Riskpada Niat Nasabah Bank Untuk Menggunakan Anjungan Tunai Mandiri (ATM)".Skripsi. Surabaya: UKWMS.

Wright, (1975). Manajemen Pemasaran Jasa, PT. Indeks, Indonesia

Wright. (2000). Consumer Acceptance of Electronic Commerce: Integrating Trust and Risk with The Technology Acceptance Model. International Journal of Electronic Commerce. Volume 7(3), pp. 69-103. 